\title{
高王濾紙電気泳動法によるアミノ酸の分離定量 (第4報) \\ Quantitative Analysis of the Amino Acids by \\ Highvoltage-paper Electrophoresis (Report 4)
}

数種食品及び蛋白質中のリデン.アルギニンの定量について

Quantitative Analysis of lysine, arginine in some foods and proteins

国立栄養研究所 (The National Institute of Nutrition)

$$
\text { 横田 フミ(Fumi YoKota) }
$$

Quantitative Analysis of the amino acids by Highvoltage-paper electrophoresis was described in our recent reports. This time, analysis of lysine and arginine in some foods and proteins was made by using this method.

〔緒言】前報において高圧濾紙電気泳動法によるアミノ酸の分離定量についてのベたが今回, 同定量法により 数種食品並びに蛋白質中のリヂン, アルギニン量を定量したのでここに報告し，あわせて他の定量法による值 と比較した。

〔実験方法】試料：数種動物性食品並びに蛋白質の加水分解物它試料として用いた。即ち, 牛肉, 豚肉, アル ブミン，カゼイン及びゼラチンの脱脂風乾物各 $0.5 \mathrm{gm}$ を取り， $4 \mathrm{~N}-\mathrm{HCl} 5 \mathrm{ml}$ を加え，オイルバス $120^{\circ} \mathrm{C} て ゙ 6$ 時間分解して試料とし\%。

分離：第 1 報の条件にしたがい高圧滤紙電気泳動法により分離した。

濾紙：東洋濾紙 No. 52

電流 : $3 \sim 5 \mathrm{~mA} / 2 \mathrm{~cm}$

電圧 : $2400 \mathrm{~V} \cdot / 45 \mathrm{~cm}$

時間：1時間15分

緩衝液：重フタール酸カリ，苛性ソーダ緩衝液，PH 5.9, イオン強度 0.098 を用いた。 定量 : 第 2 報における抽出及び比色定量法により定量した。

[実験成績]牛肉, 豚肉中のリヂン量と, 卵アルブミン, カゼイン, ゼラチン中のリギン及びアルギニン定量 值並びに文献值は第 1 表の如くである。

第 1 表 (gm/蛋白 $100 \mathrm{gm})$

\begin{tabular}{|c|c|c|c|c|}
\hline \multirow{2}{*}{ 食 品 } & \multicolumn{2}{|c|}{ リ ヂ } & \multicolumn{2}{|c|}{ アルギ = ン } \\
\hline & 定量值 & 文献值3)4) & 定量值 & 文献値3)4) \\
\hline 牛 & 9.62 & 7. $9 \sim 12.1$ & & \\
\hline 豚 & 9.95 & $7.8 \sim 9.6$ & & \\
\hline 卵アルブミ & $5 . \dot{4}$ & $3.9 \sim 7.0$ & 5.8 & $5.1 \sim 6.3$ \\
\hline カゼイ & 6.1 & $5.2 \sim 9.8$ & 3.5 & $3.2 \sim 7.3$ \\
\hline ゼ ラ. チ & 4.9 & $2.8 \sim 5.3$ & 8.3 & $5.9 \sim 9.3$ \\
\hline
\end{tabular}

本実験に当り御㸸篤な御指導御校閲を賜つ た国立栄養研究所栄養化学部長田村盈之輔博 士に深甚の感謝の意を表します。

$$
\text { 文献 }
$$

1) 田村・横田 : 栄養学雑誌, 19, 115(1961)

2) 横田：栄養学雑誌" 118(1961)

3) Richard J. Block: Amino acid hand book.

4) M. L. Orr, B. K. Watt : Amino acid content of foods (1957) (受付: 昭和36年 8 月 15日) 